PENGAJARAN DIALEK DAERAH BAGI PEMELAJAR BIPA TINGKAT A1: KAJIAN

SOSIOLINGUISTIK

\author{
Annisa Septiani \\ Universitas Ahmad Dahlan \\ annisa1900003157@webmail.uad.ac.id
}

\begin{abstract}
ABSTRAK
Kehidupan masyarakat yang semakin berkembang, bahasa digunakan untuk pelbagai kebutuhan dan kepentingan. Hal tersebut dapat terjadi karena adanya perbedaan status sosial dalam masyarakat dan situasi berbahasa. Menurut KBBI $V$, dialek merupakan variasi bahasa yang berbeda-beda menurut pemakai (misalnya bahasa dari suatu daerah tertentu, kelompok sosial tertentu, atau kurun waktu tertentu). Dialek dapat artikan juga sebagai variasi bahasa yang dibedakan atas tata bahasa, pengucapan, dan kosa kata. Setiap daerah di Indonesia menggunakan bahasa Indonesia yang dialeknya berbeda-beda. Pemelajar BIPA dapat dinyatakan berhasil ketika mereka mampu berkomunikasi bahasa Indonesia dengan penutur aslinya. Sosiolinguistik merupakan cabang dari ilmu linguistik yang mempelajari hubungan dan pengaruh antara perilaku bahasa dan perilaku sosial. Penelitian ini bertujuan untuk mengajarkan teknik-teknik pembelajaran dialek daerah oleh pemelajar BIPA tingkat A1. Metode penelitian yang digunakan berupa deskriptif kualitatif dengan pendekatan sosiolinguistik. Data penelitian diperoleh melalui teknik studi pustaka. Dalam hal ini, pengajar memiliki peran yang besar untuk mengajarkan dialek-dialek daerah yang ada di Indonesia. Mengajarkan dialek bahasa daerah dalam pengajaran BIPA, akan mempermudah pemelajar BIPA dalam berkomunikasi dengan masyarakat sekitar tempat tinggal di mana dia berada. Pemelajar BIPA selain memepelajari bahasa Indonesia standar juga mempelajari bahasa dialek di mana mereka tinggal atau di daerah di mana mereka akan tinggal, tentu akan jauh lebih mudah berkomunikasi dengan orang kebanyakan karena mereka mengerti dialek yang digunakan. Mengajarkan dialek bahasa, dimungkinkan dapat mengurangi kesalahpahaman dalam berkomunikasi dan dengan dibekali dialek bahasa tertentu, pemelajar BIPA akan lebih mudah menyesuaikan bahasa, sehingga kesalahpahaman akan bisa dikurangi.
\end{abstract}

Kata kunci: Dialek, Sosiolinguistik, Bahasa Indonesia bagi Penutur Asing (BIPA)

\title{
PENDAHULUAN
}

Era modern seperti sekarang ini, bahasa menjadi alat komunikasi setiap individu ke individu lain. Bahasa yang digunakan beragam, namun yang menjadi kebutuhan komunikasi dalam berbahasa yaitu menggunakan bahasa Negara. Menurut Nurhapsari (2017), Bahasa merupakan kumpulan simbol yang digunakan sebagai alat komunikasi. Bahasa dikatakan simbol karena ia menunjukkan identitas kelompok masyarakat secara sosiokultural. Bahasa bisa digunakan sebagai identitas sekelompok orang, satu masyarakat, satu bangsa, bahkan juga digunakan sebagai identitas global dalam lingkup antar negara. Bahasa disebut sebagai mediator karena posisinya dalam komunikasi antar manusia sebagai penghubung dan pemindah maksud sebuah interpretasi. Baik sebagai simbol dan mediator, bahasa dipandang memiliki wewenang yang sangat kuat dalam diri manusia, sekaligus sebagai ciri pembeda dengan makhluk bernyawa lainnya.

Menurut Melania W (2010), Semakin terbuka dunia global, semakin banyak pula orang belajar bahasa asing yang bertujuan untuk memenuhi kebutuhan baik dunia kerja, bisnis, sosial, pendidikan maupun budaya. Tak terkecuali orang-orang asing yang mulai mempelajari bahasa Indonesia untuk tinggal dan 
bekerja di Indonesia atau untuk belajar budaya termasuk tari dan musik Indonesia yang beraneka ragam. Pesatnya permintaan akan pengajaran Bahasa Indonesia, maka banyak lembaga yang membuka pengajaran Bahasa Indonesia untuk orang asing. Lembaga-lembaga Bahasa yang membuka program di berbagai daerah di Indonesia ini membuka program Bahasa Indonesia untuk orang asing pun mendesain kurikulum, silabus dan materi termasuk metodologi pengajaran didesain untuk memenuhi kebutuhan pencapaian bahasa mulai dari tingkat dasar sampai tingkat mahir. Materi Bahasa Indonesia standar biasanya digunakan sebagai pengantar dalam pembelajaran ini sekaligus bahasa yang dipelajari. Pada dasarnya pembelajaran bahasa Indonesia bagi orang asing harus bertujuan membuat orang yang belajar mampu berkomunikasi dengan penutur asli tanpa kesulitan yang berarti seperti dikatakan Savignon (1983) yang di kutip dalam 'language learning quotes' bahwa belajar berbicara bahasa lain berarti mengambil peran dalam komunitas yang juga berarti melampaui batas lintas budaya dan linguistik.

Pada kenyataannya, tidak semua pelajar BIPA dinyatakan cukup kemampuan berbahasanya, mereka juga sering mengalami kendala ketika berbicara di luar kelas, terlebih lagi menggunakan dialek atau bahasa daerah baru yang asing bagi mereka sehingga mereka hanya mampu menangkap sebagiannya saja. Pengajaran dialek untuk pelajar BIPA tingkat A1 perlu diselami lebih dalam untuk membangun kompetensi pelajar mahir berbahasa Indonesia dan daerah. Oleh karenanya, jurnal ini dibuat dengan tujuan untuk mengajarkan kepada pelajar BIPA tingkat A1 mengenai dialek daerah yang ada di Indonesia.

\section{LANDASAN TEORI}

Menurut Kairo: Dar Ghorib (1997 : 41), Sosiolinguistik mempelajari tentang masalah-masalah sosial dan hubungannya dengan masyarakat.131 Sosiolinguistik telah menjadi ilmu yang mandiri yang memiliki fokus kajian dalam mempelajari bahasa dan hubungannya masyarakat. Setiap sisi-sisi bangunan bahasanya sangat teratur, metode pemakaiannya berkaitan dengan fungsi-fungsi sosial dan kebudayaan. Oleh karena itu, kita harus memberikan perhatian yang dalam kepada pemakaian istilah atau satu nama sebagai tema terhadap pembahasan ini. Karena pembelajaran bahasa dan hubungannya dengan masyarakat dan kebudayaan cakupannya sangat luas sekali. Dan cukuplah kita mempelajari ilmu-ilmu atau cabang-cabang lain yang sama dengan tema ini berdasarkan pada suatu pembelajaran dengan beberapa nama yang berbeda. Akan tetapi, diantara ilmu-ilmu ini terdapat suatu keruwetan atau intervensi sebagaimana tampak dengan terang pada nama-nama yang muncul sekarang terhadap ilmu-ilmu ini yang menginginkan tema ini dari satu sisi atau sisi yang lain sebagai peran untuk pemahaman ilmu yang sebenarnya.

Sosiolinguistik merupakan gabungan dari kata Sosiologi dan Linguistik. Sosiologi adalah kajian yang objektif dan ilmiah mengenai manusia dalam masyarakat dan mengenai lembaga-lembaga serta proses sosial yang ada di dalam masyarakat. Sedangkan Linguistik adalah ilmu bahasa atau bidang yang mengambil bahasa sebagai objek kajiannya. Dengan demikian, Sosiolinguistik merupakan bidang ilmu antar disiplin atau inter dan multidisipliner yang mempelajari bahasa di dalam masyarakat. Istilah Sosiolinguistik yang menekankan tentang pengkajian bahasa dalam hubungannya dengan masyarakat, ada beberapa pakar yang 
mengemukakannya, Hymes mengemukakan bahwa, "The term Sociolinguistics to the correlations between language and societies particular linguistics and social phenomena". Artinya adalah istilah Sosiolinguistik untuk menghubungkan antara bahasa dan masyarakat serta bahasa dan fenomena dalam masyarakat.

Sosiolinguistik yang mengkaji mengenai ragam bahasa disebut variasi bahasa. Variasi atau ragam bahasa merupakan bahasan pokok dalam studi sosiolinguistik, sehingga Kridalaksana (1974) mendefinisikan sosiolinguistik sebagai cabang linguistik yang berusaha menjelaskan ciri-ciri variasi bahasa dan menetapkan korelasi ciri-ciri variasi bahasa tersebut dengan ciri-ciri sosial kemasyarakatan. Menurut Chaer dan Agustina (2014 : 61), variasi bahasa sebagai sebuah langue sebuah bahasa mempunyai sistem dan subsistem yang dipahami sama oleh semua penutur bahasa itu. Namun, karena penutur bahasa tersebut, meski berada dalam masyarakat tutur, tidak merupakan kumpulan manusia yang homogen, maka wujud bahasa yang konkret, yang disebut parole, menjadi tidak seragam. Dalam hal variasi atau ragam bahasa ini ada dua pandangan. Pertama, variasi atau ragam bahasa itu dilihat sebagai akibat adanya keragaman sosial penutur bahasa itu dan keragaman fungsi bahasa itu. Jadi variasi atau ragam bahasa itu terjadi sebagai akibat dari adanya keragaman sosial dan keragaman fungsi bahasa. Kedua, variasi atau ragam bahasa itu sudah ada untuk memenuhi fungsinya sebagai alat interaksi dalam kegiatan masyarakat yang beraneka ragam.

Variasi bahasa terbagi menjadi beberapa jenis, variasi bahasa dari segi penuturnya. Beberapa pokok pembahasan dalam variasi dari segi penutur yaitu dialek dan sosiolek. Disebut dialek, yakni variasi bahasa dari sekelompok penutur yang jumlahnya relatif, yang berada pada satu tempat, wilayah, atau area tertentu. Karena dialek ini didasarkan pada wilayah atau area tempat tinggal penutur, maka dialek ini lazim disebut dialek areal, dialek regional, atau dialek geografi. Para penutur dalam suatu dialek, meskipun mereka mempunyai idioleknya masing-masing, memiliki kesamaan ciri yang menandai bahwa mereka berada dalam dialeknya sendiri dengan ciri lain yang menandai dialeknya juga. Penggunaan istilah dialek dan bahasa dalam masyarakat umum memang seringkali bersifat ambigu. Secara linguistik jika masyarakat tutur masih saling mengerti, maka alat komunikasinya adalah dua dialek dari bahasa yang sama. Namun, secara politis, meskipun dua masyarakat tutur bisa saling mengerti karena kedua alat komunikasi verbalnya mempunyai kesamaan sistem dan subsistem, tetapi keduanya dianggap sebagai dua bahasa yang berbeda. Contohnya, bahasa Indonesia dan bahasa Malaysia, yang secara linguistik adalah sebuah bahasa, tetapi secara politis dianggap sebagai dua bahasa yang berbeda.

Variasi bahasa berdasarkan penuturnya yang lain yaitu sosiolek atau dialek sosial, yakni variasi bahasa yang berkenaan dengan status, golongan, dan kelas sosial para penuturnya. Dalam sosiolinguistik biasanya variasi inilah yang paling banyak dibicarkan dan paling banyak menyita waktu untuk membicarakannya, karena variasi ini menyangkut semua masalah pribadi para penuturnya, seperti usia, pendidikan, seks, pekerjaan, tingkat kebangsawanan, keadaan sosial ekonomi, dan sebagainya. Berdasarkan usia, kita bisa melihat perbedaan variasi bahasa yang digunakan oleh kanak-kanak, para remaja, orang dewasa, dan orang-orang yang tergolong lansia (usia lanjut). 


\section{HASIL DAN PEMBAHASAN}

Pengajaran dialek bagi pemelajar BIPA tingkat A1 dapat menggunakan model pembelajaran dengan mengajarkan dua dialek berbeda dan dari tempat yang berbeda pula. Contohnya Bahasa Jawa dan Bahasa Sunda, dari kedua dialek tersebut pemelajar BIPA harus diperkenalkan unggah-ungguh atau tata krama dalam berbicara jadi bahasa yang digunakan menggunakan krama alus. pemelajar BIPA dalam hal ini diajarkan berbicara di depan khalayak umum atau dominannya kepada orang yang lebih tua dengan menggunakan bahasa yang halus dan sopan seperti yang tercantum dalam variasi bahasa dari segi penutur yang disebut sosiolek untuk digunakan dalam kegiatan sehari-hari. Berikut ini beberapa contohnya.

\begin{tabular}{|l|l|}
\hline \multicolumn{1}{|c|}{ Dialek Bahasa Jawa } & \multicolumn{1}{|c|}{ Dialek Bahasa Sunda } \\
\hline "Kulo Nuwun" & "Punten" \\
\hline “Ndherek Langkung” & "Mangga" \\
\hline “Matur Nuwun" & "Hatur Nuhun" \\
\hline "Nyuwun Pangapunten" & "Hapunten" \\
\hline
\end{tabular}

Baris pertama, dalam bahasa Jawa disebut "Kulo Nuwun" dan dalam bahasa Sunda disebut "Punten" yang keduanya memiliki arti sama yaitu "Permisi". Penggunaan kata keduanya digunakan ketika sedang berkunjung rumah seseorang atau ketika sedang mengetuk pintu rumah seseorang tersebut. Bisa juga digunakan ketika ingin izin, bertanya, baik situasi formal maupun non formal. Baris kedua, dalam bahasa Jawa disebut "Ndherek Langkung” dan dalam bahasa Sunda disebut "Mangga” yang keduanya memiliki arti sama yaitu "Mari". Kata "Mari" dalam hal ini bukan suatu ajakan, melainkan sapaan ketika berlalu lalang dengan orang yang lebih tua dengan menundukkan kepala dan sedikit senyuman supaya terkesan sopan dan menghargai mereka. Baris ketiga, dalam bahasa Jawa disebut "Matur Nuwun" dan dalam bahasa Sunda disebut "Hatur Nuhun" yang keduanya memiliki arti sama yaitu "Terima Kasih", kata tersebut dapat digunakan baik dalam situasi formal maupun non formal. Biasanya kata tersebut diucapkan ketika mendapat barang atau hadiah, ketika mendapat jawaban dari pertanyaan pemelajar, ketika mendapatkan pertolongan, dan lainnya. Kata "Terima Kasih" menjadi suatu ucapan yang paling wajib diucapkan sebagai rasa syukur atas pertolongan yang telah diberikan dengan memberikan senyuman tulus. Baris keempat, dalam bahasa Jawa disebut "Nyuwun Pangapunten" dan dalam bahasa Sunda disebut "Hapunten" yang keduanya memiliki arti sama yaitu "Mohon Maaf", kata ini biasanya ditujukan ketika kita memiliki kesalahan baik yang disengaja maupun tidak, baiknya kata ini bisa digunakan dalam berbagai situasi dan dominannya diucapkan kepada yang lebih tua untuk menghormati mereka. 


\section{SIMPULAN}

Mengajarkan dialek bahasa daerah dalam pengajaran BIPA, akan mempermudah pemelajar BIPA terutama tingkat A1 dalam berkomunikasi dengan masyarakat sekitar tempat tinggal dimana dia berada. Pemelajar BIPA selain mempelajari Bahasa Indonesia Standar juga mempelajari bahasa dialek dimana mereka tinggal atau di daerah dimana mereka akan tinggal, tentu akan jauh lebih mudah berkomunikasi dengan orang kebanyakan karena mereka mengerti dialek yang digunakan. Dengan hanya mengerti Bahasa Indonesia standar mereka bisa berbicara dengan orang yang sama-sama menggunakan standar saja dan mereka mungkin hanya mengalami sedikit kendala, namun ketika mendengar orang Indonesia menggunakan dialek tertentu, akan timbul kesulitan yang cukup berarti jika mereka tidak dibekali dengan bahasa dialek. Selain itu, dengan mengajarkan dialek bahasa dialek, dimungkinkan dapat mengurangi kesalah-pahaman dalam berkomunikasi. Dengan dibekali dialek bahasa tertentu, pemelajar BIPA akan lebih mudah menyesuaikan bahasa, sehingga kesalah pahaman akan bisa dikurangi. Jika hanya hanya menggunakan Bahasa Indonesia standar, kemungkinan akan lebih banyak timbul kesalah pahaman karena kata, intonasi dan susunan kalimat yang terbalik akan menimbulkan arti yang berbeda. Mengajarkan Dialek Bahasa Jawa dan Bahasa Sunda sebagai pondasi awal, dapat membuka pandangan mereka mengenai adanya ragam bahasa yang ada di Indonesia sehingga mereka tertarik untuk mengetahui bahasa Indonesia beserta kekayaannya lebih dalam lagi.

\section{DAFTAR PUSTAKA}

Chaer, A \& Agustina, L. 2014. Sosiolinguistik Perkenalan Awal. Jakarta: Rineka Cipta.

Muliastuti, Liliana. 2019. Bahasa Indonesia bagi Penutur Asing “Acuan Teori dan Pendekatan Pengajaran”. Jakarta: Yayasan Pustaka Obor Indonesia.

Wiannastiti, Melania. 2010. Pengajaran Dialek Daerah Dalam Pengajaran BIPA Penting atau Tidak Penting?. Diakses melalui google cendekia https://journal.binus.ac.id/index.php/Humaniora/article/view/2873 pada tanggal 12 April 2021.

Paramitha, N. P. 2017. Implementasi Pendekatan Sosiolinguistik Dalam Pembelajaran Bahasa Arab. https://journal.staimsyk.ac.id/index.php/almanar/article/view/75 pada tanggal 14 April 2021. 